\title{
Association of the HtrA1 rs11200638 Polymorphism with Neovascular Age-Related Macular Degeneration in Indonesia
}

\author{
Supanji Supanji (D) Ayudha Bahana Ilham Perdamaian · \\ Dewi Fathin Romdhoniyyah • Muhammad Bayu Sasongko • \\ Angela Nurini Agni · Firman Setya Wardhana · Tri Wahyu Widayanti • \\ Muhammad Eko Prayogo · Chio Oka · Masashi Kawaichi
}

Received: August 4, 2021 / Accepted: September 24, 2021 / Published online: November 2, 2021

(C) The Author(s) 2021

\section{ABSTRACT}

Introduction: The aim of this study was to investigate the association of the HtrA1 rs11200638 polymorphism with neovascular age-related macular degeneration (nAMD) in Indonesia.

S. Supanji $(\bowtie) \cdot$ A. B. I. Perdamaian ·

D. F. Romdhoniyyah - M. B. Sasongko .

A. N. Agni · F. S. Wardhana - T. W. Widayanti ·

M. E. Prayogo

Department of Ophthalmology, Faculty of Medicine Public Health and Nursing, Universitas Gadjah

Mada, Jalan Farmako Sekip Utara, Yogyakarta

55281, Indonesia

e-mail: supanji@ugm.ac.id

S. Supanji · A. B. I. Perdamaian

· D. F. Romdhoniyyah · M. B. Sasongko ·

A. N. Agni - F. S. Wardhana - T. W. Widayanti .

M. E. Prayogo

Dr. Sardjito General Hospital, Yogyakarta, Indonesia

S. Supanji

Ophthalmology Clinic, Military Air Force Central

Hospital Dr. Suhardi Hardjolukito, Yogyakarta,

Indonesia

S. Supanji - M. B. Sasongko - A. N. Agni ·

F. S. Wardhana - T. W. Widayanti - M. E. Prayogo

Ophthalmology Clinic, Dr. YAP Eye Hospital,

Yogyakarta, Indonesia

C. Oka · M. Kawaichi

Laboratory of Gene Function in Animals, Nara

Institute of Science and Technology, Ikoma, Nara, Japan
Methods: This case-control study included 80 patients with nAMD and 85 controls. Demographic parameters and whole blood were collected from each participant. Genomic DNA was extracted and used to assess the rs11200638 genotype by PCR and restriction enzyme digestion. Associations between the HtrA1 rs11200638 polymorphism and other risk factors for susceptibility to nAMD were assessed using the logistic regression model.

Results: Significant allelic associations between the HtrA1 polymorphism and nAMD were detected (odds ratio [OR] 8.67; 95\% confidence interval [CI] 4.88-15.41; $P<0.001$ ). Genotype analysis showed a statistical difference between the nAMD group and the control group $(P<0.001)$. In the multiple adjusted logistic regression model, people with the AA genotype were more likely to have nAMD although there was a wide confidence interval (OR 19.65; 95\% CI 4.52-85.38; $P<0.001)$.

Conclusion: Our findings show that the risk of nAMD increased in the presence of risk alleles of HtrA1 rs11200638.

Keywords: Age-related macular degeneration; HtrA1; Polymorphism 


\section{Key Summary Points}

The HtrA1 rs11200638 polymorphism is associated with the risk of neovascular age-related macular degeneration (nAMD) in Indonesian patients.

The presence of hypertension compounds the genetic risk for nAMD.

The results of this study are in accordance with those of other epidemiological studies involving patients of different ethnicity in supporting the hypothesis that HtrA1 contributes to the risk of nAMD.

\section{INTRODUCTION}

Age-related macular degeneration (AMD) is a progressive degenerative disease affecting the macula and is among the five leading causes of vision loss worldwide [1]. AMD results from a sequence of deterioration processes that occur in photoreceptors, the retinal pigment epithelium (RPE), and Bruch's membrane (BM). These result in an irreversible lesion that manifests clinically as geographic atrophy (dry AMD) or they cause aberrant blood vessels originating from the choroid to leak at the macular region (neovascular AMD [nAMD]). If untreated, these conditions can lead to permanent vision loss. It is notable that that not all aged individuals follow the similar processes and develop AMD, implying a genetic-driven pathophysiology of the disease process.

High-temperature requirement A1 (HtrA1) is one of important genetic factors in nAMD etiology, in addition to Age-related maculopathy susceptibility 2 (ARMS2) and Complement factor $\mathrm{H}(\mathrm{CFH})$. The HtrA1 genetic variant rs11200638 is located precisely at the HtrA1 promoter. The three most strongly associated loci identified to date are located on chromosome one (1q31), CFH (rs1061170), chromosome 10 (10q26), ARMS2 (rs10490924; del443ins54), and HtrA1 (rs11200638) [2]. In an earlier study, we have shown that the ARMS2 rs10490924 and del443ins54 variants show a strong association with nAMD in Indonesia [3]. The position of the rs11200638 polymorphism in the genome is very close to those of the rs10490924 and del443ins54 polymorphisms [4-7]. These single nucleotide polymorphisms segregate together during chromosome crossing-over, resulting in almost all cases having the same status (wildtype, carrier, and mutant homozygote) with each other. Research has also shown that these two loci are highly predictive (i.e., in near perfect linkage disequilibrium $\left.\left[D^{\prime}>0.98\right]\right)$ for AMD [7]. Therefore, investigation of the presence of the rs11200638 polymorphism in Indonesia will provide a large overview of the epidemiology and pathogenesis of nAMD.

Replication studies on different ethnic populations show consistent results [7-20], but there are no reports on Indonesian populations. In addition to CFH and ARMS2 [3], no other genetics factors have been examined in Indonesia. The aim of this study was to investigate the associations of HtrA1 with nAMD in the Indonesian population, of which the majority ethnic group is the Asian Malay group.

\section{METHODS}

This case-control study included participants aged $\geq 45$ years. Between 2016 and 2018 we recruited 80 patients with nAMD and 85 agematched control participants into this study.The purpose of the research and the procedures were fully explained prior to the participants signing an informed consent form and undergoing blood collection and comprehensive ophthalmologic examinations. The study was approved by the Medical and Health Research Ethics Committee of the Faculty of Medicine, Public Health and Nursing, Universitas Gadjah Mada (ethics number: KE/FK/864/EC [5 August 2016]; KE/FK/1109/EC/2017 [12 October 2017]; KE/FK/1108/EC/2018 [18 October 2018]). This study adhered to the ethical standards of the Declaration of Helsinki of 1964 and its later amendments. The inclusion/exclusion criteria 
and the criteria for AMD diagnosis were as reported previously [3].

\section{Genotyping}

The procedures followed for extraction of the genomic DNA and gene amplification were as described previously [3]. The primer sequences were: forward 5'-TTCCCATCTGAGACCGCT-3' and reverse $5^{\prime}$-GGAAAGTTCCTGCAAATCG-3' [17]. The PCR cycling conditions were: 1 cycle of $95^{\circ} \mathrm{C}$ for $10 \mathrm{~min}$, followed by 35 cycles of $95{ }^{\circ} \mathrm{C}$ for $45 \mathrm{~s}, 55^{\circ} \mathrm{C}$ for $45 \mathrm{~s}, 72^{\circ} \mathrm{C}$ for $45 \mathrm{~s}$, with a final cycle of $72{ }^{\circ} \mathrm{C}$ for $5 \mathrm{~min}$. For genotype discrimination, the 400-bp amplicon was digested with $5 \mathrm{U}$ of EagI restriction enzyme (New England BioLabs, Ipswich. MA, USA) by an overnight incubation at $37^{\circ} \mathrm{C}$. Following electrophoresis in $2 \%$ agarose gels, the DNA bands were visualized with fluorosafe DNA staining (1st Base Asia, Selangor, Malaysia; Cat. No. BIO$5170-1 \mathrm{ml})$. The undigested samples were determined to be the AA genotype, whereas the partially or totally digested samples were designated the AG or GG genotype. Sanger sequencing was used to verify each genotype (AA; GA; GG) in the nAMD patient and control groups.

\section{Statistical Analysis}

A complete case analysis of those with complete covariate and genetic data was performed. Statistical analysis, including the Hardy-Weinberg equilibrium (HWE) test and multivariable logistic regression, were performed using STATA ${ }^{\circledR}$ version 16 (StataCorp, College Station, TX, USA) as reported previously [3].

\section{RESULTS}

Blood samples were collected from 80 patients with nAMD and 85 controls, all of whom were Indonesian. The cases and controls were similar in terms of demographic data (Table 1). The average age of the patient and control groups was 67.3 and 68.2 years, respectively; 50.0 and $54.0 \%$ of the patient and control groups were
Table 1 Demographic characteristics of study participants

\begin{tabular}{|c|c|c|c|}
\hline $\begin{array}{l}\text { Demographic } \\
\text { characteristics }\end{array}$ & $\begin{array}{l}\text { Case group } \\
(n=\mathbf{8 0})\end{array}$ & $\begin{array}{l}\text { Control } \\
\text { group } \\
(n=85)\end{array}$ & $P$ \\
\hline Age, years & & & 0.49 \\
\hline $\begin{array}{l}\text { Range } \\
\text { (median) }\end{array}$ & $\begin{array}{r}45-82 \\
(67.5)\end{array}$ & 49-99 (69) & \\
\hline Mean $\pm S D$ & $67.3 \pm 8.4$ & $68.2 \pm 7.8$ & \\
\hline Sex & & & 0.55 \\
\hline Male & $33(41.0 \%)$ & 39 (46.0\%) & \\
\hline Female & $47(59.0 \%)$ & $46(54.0 \%)$ & \\
\hline BMI $\left(\mathrm{kg} / \mathrm{m}^{2}\right)$ & & & 0.02 \\
\hline $\begin{array}{l}\text { Range } \\
\text { (median) }\end{array}$ & $\begin{array}{c}16.7-37.1 \\
(23.3)\end{array}$ & $\begin{array}{c}15.2-36.8 \\
(21.5)\end{array}$ & \\
\hline Mean $\pm S D$ & $23.6 \pm 3.5$ & $22.2 \pm 4.2$ & \\
\hline $\begin{array}{l}\text { Sunlight } \\
\text { exposure }\end{array}$ & & & 0.92 \\
\hline $\begin{array}{l}\text { Indoor } \\
\text { workplace }\end{array}$ & $58(72.0 \%)$ & $61(72.0 \%)$ & \\
\hline $\begin{array}{l}\text { Outdoor } \\
\text { workplace }\end{array}$ & $22(28.0 \%)$ & $24(28.0 \%)$ & \\
\hline Smoking & & & 0.75 \\
\hline Never & $61(76.0 \%)$ & $63(74.0 \%)$ & \\
\hline Ever & $19(24.0 \%)$ & $22(26.0 \%)$ & \\
\hline Blood pressure & & & $<0.001$ \\
\hline $\begin{array}{l}\text { Normal blood } \\
\text { pressure }\end{array}$ & $44(55.0 \%)$ & $68(80.0 \%)$ & \\
\hline $\begin{array}{l}\text { High blood } \\
\text { pressure }\end{array}$ & $36(45.0 \%)$ & $17(20.0 \%)$ & \\
\hline
\end{tabular}

$B M I$ Body mass index, $n A M D$ neovascular age-related macular degeneration, $S D$ standard deviation

female; and the mean body mass index (BMI) for AMD cases and controls was 23.6 and $22.2 \mathrm{~kg} / \mathrm{m}^{2}$, respectively. Most participants were predominantly working indoors with less exposure to sunlight ( $72 \%$ for both AMD cases and controls). The number of AMD patients 
with high blood pressure was significantly higher in the nAMD group than in the controls.

The allele and genotype distributions of the HtrA1 rs11200638 polymorphism are summarized in Table 2. Comparison of the cases and controls revealed a statistically significant difference in the allele or genotype distributions of HtrA1 rs11200638 $(P<0.001)$. The A allele frequency was $88.7 \%$ in nAMD patients and $42.2 \%$ in controls. There was a higher percentage of AA genotypes in the nAMD group (77.4\%) than in the control group (22.6\%), and the opposite was true for AG genotypes, which were less frequent in the nAMD group (21.8\%) than in the control group $(76.2 \%)$. The unconditional logistic regression analysis showed that the A allele was associated with an increased risk of nAMD (odds ratio [OR] 8.67; 95\% confidence Interval [CI] 4.88-15.41; $P<0.001)$. Similarly, an association was found in adjusted logistic regression model with a per-A-allele OR of $3.73 \quad(95 \%$ CI 1.11-12.56; $P=0.034$ ).

Individuals with the AA genotype were found to have strong association with nAMD in the unadjusted logistic regression analysis (OR 26.23; 95\% CI: 7.10-96.93; $P<0.001$ ), age- and sex-adjusted logistic regression analysis (OR
26.85; 95\% CI 7.10-101.49), and the multiple variable logistic regression analysis (OR 19.65; 95\% CI 4.52-85.38; $P<0.001$ ) (Table 3). Additionally, the multiple variable logistic regression analysis showed that hypertension was associated with an increased risk for nAMD (OR 3.4; 95\% CI 1.30-8.95; $P=0.013)$. No significant association was found between BMI and smoking with nAMD in the multiple variable logistic regression analysis $(P \geq 0.05)$.

\section{DISCUSSION}

We identified an association between the HtrA1 rs11200638 polymorphism and nAMD in an Indonesian population. However, these results should be interpreted cautiously due to the wide confidence interval, possibly due to the small sample size [21]. The findings from this gender and age-matched case-control study suggest that either A alleles or AA genotypes of the HtrA1 rs11200638 polymorphism were associated with the onset of nAMD. Patients with the AA genotype were more prone to have AMD by nearly 26-fold. The association remained strong after data adjustment with

Table 2 Distribution of alleles and genotypes of the HtrA1 rs11200638 polymorphism

\begin{tabular}{|c|c|c|c|c|c|c|c|c|}
\hline \multirow[t]{2}{*}{ Allele } & \multicolumn{2}{|c|}{ Allele distribution, $n$ (\%) } & \multirow[t]{2}{*}{$P$} & \multirow[t]{2}{*}{ Genotype } & \multicolumn{2}{|c|}{ Genotype distribution, $n$ (\%) } & \multirow[t]{2}{*}{$P$ value } & \multirow[t]{2}{*}{$P($ HWE $)$} \\
\hline & Case group & $\overline{\text { Control group }}$ & & & Case group & Control group & & \\
\hline G & $18(11.3 \%)$ & $89(57.8 \%)$ & $<0.001$ & GG & $3(11.5 \%)$ & $23(88.5 \%)$ & $<0.001$ & 0.204 \\
\hline \multirow[t]{2}{*}{ A } & $142(88.7 \%)$ & $65(42.2 \%)$ & & GA & $12(21.8 \%)$ & $43(76.2 \%)$ & & \\
\hline & & & & AA & $65(77.4 \%)$ & $19(22.6 \%)$ & & \\
\hline
\end{tabular}

CI Confidence interval, $H W E$ Hardy-Weinberg equilibrium in control group, $O R$ odds ratio

Table 3 Association between the HtrAI rs11200638 polymorphism and nAMD in an Indonesian population

\begin{tabular}{llllllll}
\hline Genotype & Crude OR (95\% CI) & $\boldsymbol{P}$ & \multicolumn{1}{c}{ Adjusted OR (95\% CI) } & $\boldsymbol{P}$ & \multicolumn{2}{c}{${\text { Adjusted OR }(\mathbf{9 5 \%} \mathbf{C I})^{\mathbf{b}}}^{\mathbf{P}}$} \\
\hline GG & 1.00 (reference) & - & 1.00 (reference) & - & 1.00 (reference) & - \\
GA & $2.14(0.55-8.36)$ & 0.274 & $1.80(0.45-7.22)$ & 0.409 & $1.37(0.30-6.21)$ & 0.683 \\
AA & $26.23(7.10-96.93)$ & $<0.001$ & $26.85(7.10-101.49)$ & $<0.001$ & $19.65(4.52-85.38)$ & $<0.001$ \\
\hline
\end{tabular}

a Adjusted for age and sex

b Adjusted for smoking, body mass index, and blood pressure 
Table 4 Results from studies on the association between the HtrAl polymorphism and nAMD

\begin{tabular}{|c|c|c|c|c|}
\hline References & Location & Ethnicity & Sample & OR $(95 \% \mathrm{CI})$ \\
\hline $\begin{array}{l}\text { DeWan } \\
\text { et al. [8] }\end{array}$ & China & Chinese & 96 cases and 130 controls $^{\mathrm{a}}$ & $\mathrm{OR}_{\mathrm{hom}}=10(4.38-22.82)$ \\
\hline $\begin{array}{l}\text { Mori et al. } \\
\quad[13]\end{array}$ & Japan & East Asian & 123 cases and 133 controls $^{a}$ & $\mathrm{OR}_{\text {hom }}=5.59(2.66-11.76)$ \\
\hline $\begin{array}{l}\text { Lin et al. } \\
\quad[14]\end{array}$ & Taiwan & $\begin{array}{r}\text { Taiwanese } \\
\text { Chinese }\end{array}$ & 95 cases and 90 controls $^{\mathrm{b}}$ & $\begin{array}{l}\mathrm{OR}_{\text {het }}=1.97(0.81-4.81) \\
\mathrm{OR}_{\text {hom }}=8.59,(3.28-22.49)\end{array}$ \\
\hline $\begin{array}{l}\text { Yan et al. } \\
{[25]}\end{array}$ & China & $\begin{array}{l}\text { Han } \\
\text { Chinese }\end{array}$ & 109 cases, 150 controls & $\begin{array}{l}\text { OR GA }+ \text { AA }=2.02 \\
(1.20-3.39)\end{array}$ \\
\hline $\begin{array}{l}\text { Tam et al. } \\
{[15]}\end{array}$ & China & Chinese & 163 cases and 183 controls $^{\mathrm{b}}$ & $\begin{array}{l}\mathrm{OR}_{\text {het }}=1.88(0.96-3.66) \\
\mathrm{OR}_{\text {hom }}=7.6(3.94-14.51)\end{array}$ \\
\hline $\begin{array}{l}\text { Gong et al. } \\
{[16]}\end{array}$ & China & Chinese & 99 cases and 73 controls & $\mathrm{OR}_{\mathrm{hom}}=4.19(2.28-7.70)$ \\
\hline $\begin{array}{l}\text { Lana et al. } \\
\text { [17] }\end{array}$ & Brazil & $\begin{array}{l}\text { South } \\
\text { American }\end{array}$ & 204 cases and 166 controls & $\begin{array}{l}\mathrm{OR}_{\text {hom }}=25.97 \pm 4.42 \\
\quad(16.75-34.32)\end{array}$ \\
\hline $\begin{array}{l}\text { Abbas and } \\
\text { Azzazy } \\
{[18]}\end{array}$ & Egypt & Arabic & 26 cases and 20 controls & $\mathrm{OR}_{\text {het }+ \text { hom }}=6(1.4-24.7)$ \\
\hline $\begin{array}{l}\text { Kaur et al. } \\
\text { [19] }\end{array}$ & India & East Asian & 250 cases and 250 controls & $\mathrm{OR}_{\mathrm{hom}}=6.69(3.69-12.10)$ \\
\hline $\begin{array}{l}\text { Matušková } \\
\text { et al. [24] }\end{array}$ & $\begin{array}{l}\text { Czech } \\
\text { Republic }\end{array}$ & $\begin{array}{l}\text { Czech } \\
\text { population }\end{array}$ & 307 cases and 191 controls & $\mathrm{OR}=16.02(5.4-47.54)$ \\
\hline $\begin{array}{l}\text { Francis } \\
\quad \text { et al. [20] }\end{array}$ & $\begin{array}{l}\text { Northern } \\
\text { Europe }\end{array}$ & Caucasian & 333 cases and 171 controls $^{a}$ & $\mathrm{OR}_{\text {hom }}=3.973(2.928-5.390)$ \\
\hline $\begin{array}{l}\text { Gili et al. } \\
\text { [9] }\end{array}$ & Spain & $\begin{array}{l}\text { Spanish } \\
\text { Caucasian }\end{array}$ & 187 cases and 196 controls & $\mathrm{OR}_{\mathrm{hom}}=6.44(3.62-11.47)$ \\
\hline $\begin{array}{l}\text { Yang et al. } \\
{[10]}\end{array}$ & USA & Caucasian & 581 cases and 309 controls & $\begin{array}{l}\mathrm{OR}_{\text {het }}=1.90(1.40,2.58) \\
\mathrm{OR}_{\text {hom }}=7.51(3.75,15.04)\end{array}$ \\
\hline $\begin{array}{l}\text { Gibbs et al. } \\
\text { [7] }\end{array}$ & USA & Caucasian & 342 cases and 215 controls $^{\mathrm{b}}$ & \\
\hline $\begin{array}{l}\text { Chen et al. } \\
{[12]}\end{array}$ & USA & Caucasian & $\begin{array}{l}774 \text { cases and } 294 \text { controls }^{\mathrm{b}} \text {; } 192 \text { bilateral } \\
\text { nAMD, } 278 \text { unilateral nAMD, } 234 \\
\text { bilateral GA, } 72 \text { unilateral GA }\end{array}$ & $\begin{array}{l}\text { Bil } \mathrm{OR}_{\text {hom }}=10.95(5.26-22.77) \\
\text { Uni } \mathrm{OR}_{\text {hom }}=5.62(2.65-11.90)\end{array}$ \\
\hline $\begin{array}{l}\text { DeAngelis } \\
\text { et al. [11] }\end{array}$ & USA & Caucasian & 73 sib pairs $^{c}$ & $\begin{array}{c}\mathrm{OR}_{\text {hom }}=98.41(13.45-720.08 \\
\left.P<10^{-5}\right) \mathrm{OR}_{\text {het }}=6.05 \\
\left(2.13-17.21 ; \quad P<10^{-3}\right)\end{array}$ \\
\hline
\end{tabular}


Table 4 continued

\begin{tabular}{|c|c|c|c|c|}
\hline References & Location & Ethnicity & Sample & OR (95\% CI) \\
\hline $\begin{array}{l}\text { Mohamad } \\
\text { et al. [23] }\end{array}$ & Malaysia & Asian & 145 cases, 145 controls & $\mathrm{OR}_{\text {hom }}=1.52(1.07-2.15)$ \\
\hline
\end{tabular}

smoking, BMI, and blood pressure. People with the AA genotype had a 20-fold increased risk of having nAMD than those with the GG genotype. This finding is similar to results from other studies in other ethnic groups [12, 17-19, 22-24].

An association between HtrA1 and nAMD has also been found in other countries (Table 4). In Southeast Asia, similar results were also reported in Malaysia [23].

The HtrA1 rs11200638 polymorphism is widely reported to be highly associated with the risk for nAMD worldwide. Epidemiological studies have shown that, compared to people with the GG genotype, those with the AA genotype in the Chinese population have a tenfold increased risk for nAMD [8] and their Caucasian counterparts have a 7.5-fold increased risk [10]. This higher risk of AA genotype for nAMD was reconfirmed in other studies involving Caucasian populations [7, 12]. The A allele and AA genotypes have also associated with the dry forms of AMD in addition to nAMD in Chinese Taiwanese subjects [14]. Another Chinese study showed a 7.6-fold increased risk in subjects with the A allele, with smoking status compounding the risk to 15.7fold [15]. Studies in Middle East [18], India [19], and Brazil [17] have shown similar results. Individuals with the AG and AA genotype have been found to have a 2.2- and 8.7-fold higher risk of developing AMD, respectively, when compared with those who carry the GG genotype [26].

The HtrA1 gene encodes a serine protease, and this protease is produced by many tissues, including the RPE [27]. This protein plays an important role in the breakdown of many components of the extracellular matrix (ECM) [27-29]. It has been hypothesized that these breakdowns of ECM proteins is related to development of neovascularization [27, 29].

A high concentration of HtrA1 has been found in the aqueous humor of nAMD patients, with subsequent decrease following intravitreal injections of $0.5 \mathrm{mg}$ ranibizumab [31]. The HtrA1 polymorphism was also reported to be associated with the AMD onset in the second eye [12]. The association of the HtrA1 polymorphism to the response to ranibizumab treatment in nAMD has not been consistent in studies [23, 26, 32, 33]

The main limitations of our study are the small sample size and the hospital-based design. The design may have only captured the advanced profiles of AMD patients, thereby masking the true representation of AMD in general population. Future studies should include larger and more diverse sample sizes to allow subanalyses based on ethnic origin in Indonesia. Identifying other target genes related to AMD in the Indonesian population is also warranted as this study is only the second study on the genetic factors associated with nAMD and only the second study on AMD in Indonesia.

\section{CONCLUSIONS}

We identified that the HtrA1 rs11200638 polymorphism is significantly associated with risk of nAMD albeit with a wide confidence interval. 


\section{ACKNOWLEDGEMENTS}

We sincerely thank the participants of this study.

Funding. The journal's Rapid Service Fees, were financially supported by the Publishers and Publication Board (Badan Penerbit dan Publikasi; BPP) of Gadjah Mada University. The study was supported by Faculty of Medicine, Public Health, and Nurse (FK-KMK), Gadjah Mada University through the DAMAS research fund 2021 (No.: 269/UNI1/FKKMK/PPKE/PT/ 2021).

Editorial Assistance. Editorial assistance in the preparation of this article was provided by Klinik Bahasa, Office of Research and Publication, Faculty of Medicine Public Health and Nursing, Universitas Gadjah Mada, Yogyakarta, Indonesia.

Authorship. All named authors meet the International Committee of Medical Journal Editors (ICMJE) criteria for authorship for this article, take responsibility for the integrity of the work as a whole, and have given their approval for this version to be published.

Author Contributions. Supanji Supanji (Principal Investigator): conceptualization, methodology, research funding application, data collection and investigation, writing-reviewing and editing, and supervision. Ayudha Bahana Ilham: data collection and investigation, and writing-original draft. Dewi Fathin Romdhoniyyah: data collection and investigation, data analysis and interpretation, and writing-original draft. Muhammad Bayu Sasongko: data collection and investigation, data analysis and interpretation, writing-reviewing, and editing. Angela Nurini Agni: data collection and investigation, writing-reviewing, and editing. Firman Setya Wardhana: data investigation, writing-reviewing, and editing. Tri Wahyu Widayanti: data investigation, writing-reviewing and editing. Muhammad Eko Prayogo: data investigation, writing-reviewing, and editing. Chio Oka: conceptualization, data interpretation, writing-reviewing, and editing. Masashi Kawaichi: conceptualization, data interpretation, writing-reviewing, and editing. All authors read and approved the final manuscript.

Disclosures. Supanji Supanji, Ayudha Bahana Ilham Perdamaian, Dewi Fathin Romdhoniyyah, Muhammad Bayu Sasongko, Angela Nurini Agni, Firman Setya Wardhana, Tri Wahyu Widayanti, Muhammad Eko Prayogo, Chio Oka, Masashi Kawaichi all declare they have nothing to disclose.

Compliance with Ethics Guidelines. The purpose of the research and the procedures were fully explained prior to the participants signing an informed consent form and undergoing blood collection and comprehensive ophthalmologic examinations. The study was approved by the Medical and Health Research Ethics Committee of the Faculty of Medicine, Public Health and Nursing, Universitas Gadjah Mada (ethics number: KE/FK/864/EC [5 August 2016]; KE/FK/1109/EC/2017 [12 October 2017]; KE/FK/ 1108/EC/2018 [18 October 2018]).

Data Availability. The datasets generated during and/or analyzed during the current study are available from the corresponding author on reasonable request.

Open Access. This article is licensed under a Creative Commons Attribution-NonCommercial 4.0 International License, which permits any non-commercial use, sharing, adaptation, distribution and reproduction in any medium or format, as long as you give appropriate credit to the original author(s) and the source, provide a link to the Creative Commons licence, and indicate if changes were made. The images or other third party material in this article are included in the article's Creative Commons licence, unless indicated otherwise in a credit line to the material. If material is not included in the article's Creative Commons licence and your intended use is not permitted by statutory regulation or exceeds the permitted use, you will need to obtain permission directly from the copyright holder. To view a copy of this licence, 
visit http://creativecommons.org/licenses/bync/4.0/.

\section{REFERENCES}

1. Flaxman SR, et al. Global causes of blindness and distance vision impairment 1990-2020: a systematic review and meta-analysis. Lancet Glob Health. 2017;5(12):e1221-34. https://doi.org/10.1016/S22 14-109X(17)30393-5.

2. Fritsche LG, et al. A large genome-wide association study of age-related macular degeneration highlights contributions of rare and common variants. Nat Genet. 2016;48(2):134-43. https://doi.org/10. 1038/ng.3448.

3. Supanji S, et al. Associations of arms 2 and $c$ fh gene polymorphisms with neovascular age-related macular degeneration. Clin Ophthalmol. 2021;15: 1101-8. https://doi.org/10.2147/OPTH.S298310.

4. Fritsche LG, et al. Age-related macular degeneration is associated with an unstable ARMS2 (LOC387715) mRNA. Nat Genet. 2008;40:892. https://doi.org/10. 1038/ng.170.

5. Wang G, et al. Analysis of the indel at the ARMS2 3'UTR in age-related macular degeneration. Hum Genet. 2010;127(5):595-602. https://doi.org/10.10 07/s00439-010-0805-8.

6. Friedrich U, et al. Risk-and non-risk-associated variants at the 10q26 AMD locus influence ARMS2 mRNA expression but exclude pathogenic effects due to protein deficiency. Hum Mol Genet. 2011;20(7):1387-99. https://doi.org/10.1093/hmg/ ddr020.

7. Gibbs D, et al. Further mapping of 10q26 supports strong association of HTRA1 polymorphisms with age-related macular degeneration. Vis Res. 2008; 48(5):685-9. https://doi.org/10.1016/j.visres.2007. 10.022 .

8. DeWan A, et al. HTRA1 promoter polymorphism in wet age-related macular degeneration. Science. 2006;314(5801):989-92. https://doi.org/10.1126/sci ence. 1133807.

9. Gili P, et al. Gene polymorphisms associated with an increased risk of exudative age-related macular degeneration in a Spanish population. Eur J Ophthalmol. 2021. https://doi.org/10.1177/112067212 11002698.

10. Yang Z, et al. A variant of the HTRA1 gene increases susceptibility to age-related macular degeneration.
Science. 2006;314(5801):992-3. https://doi.org/10. 1126/science. 1133811 .

11. DeAngelis MM, et al. Alleles in the HtrA serine peptidase 1 gene alter the risk of neovascular agerelated macular degeneration. Ophthalmology. 2008;115(7):1209-15.e7. https://doi.org/10.1016/j. ophtha.2007.10.032.

12. Chen $\mathrm{H}$, et al. Association of HTRA1 polymorphism and bilaterality in advanced age-related macular degeneration. Vis Res. 2008;48(5):690-4. https:// doi.org/10.1016/j.visres.2007.10.014.

13. Mori K, et al. Association of the HTRA1 gene variant with age-related macular degeneration in the Japanese population. J Hum Genet. 2007;52(7):636-41. https://doi.org/10.1007/s10038-007-0162-1.

14. Lin JM, et al. HTRA1 polymorphism in dry and wet age-related macular degeneration. Retina. 2008; 28(2):309-13. https://doi.org/10.1097/IAE.0b013e3 1814cef3a.

15. Tam POS, et al. HTRA1 variants in exudative agerelated macular degeneration and interactions with smoking and CFH. Investig Ophthalmol Vis Sci. 2008;49(6):2357-65. https://doi.org/10.1167/iovs. $07-1520$.

16. Gong Y, et al. Association of HTRA1 and CFH gene polymorphisms with age-related macular degeneration in Ningbo, China. Int Ophthalmol. 2021;41(3):995-1002. https://doi.org/10.1007/s107 92-020-01655-3.

17. Lana TP, et al. Association of HTRA1 rs11200638 with age-related macular degeneration (AMD) in Brazilian patients. Ophthalmic Genet. 2018;39(1): 46-50. https://doi.org/10.1080/13816810.2017.135 4382 .

18. Abbas RO, Azzazy HME. Association of single nucleotide polymorphisms in CFH, ARMS2 and HTRA1 genes with risk of age-related macular degeneration in Egyptian patients. Ophthalmic Genet. 2013;34(4):209-16. https://doi.org/10.3109/ 13816810.2012 .762934 .

19. Kaur I, et al. Variants in the 10q26 gene cluster (LOC387715 and HTRA1) exhibit enhanced risk of age-related macular degeneration along with $\mathrm{CFH}$ in Indian patients. Investig Ophthalmol Vis Sci. 2008;49(5):1771-6. https://doi.org/10.1167/iovs.070560 .

20. Francis PJ, Zhang H, DeWan A, Hoh J, Klein ML. Joint effects of polymorphisms in the HTRA1, LOC387715/ARMS2, and CFH genes on AMD in a Caucasian population. Mol Vis. 2008;14: 1395-1400. http://www.molvis.org/molvis/v14/a1 68. 
21. Hazra A. Using the confidence interval confidently. J Thorac Dis. 2017;9(10):4125-30.

22. Tian J, et al. Association of genetic polymorphisms and age-related macular degeneration in Chinese population. Investig Ophthalmol Vis Sci. 2012; 53(7):4262-9. https://doi.org/10.1167/iovs.11-8542.

23. Mohamad NA, et al. Association of HTRA1 and ARMS2 gene polymorphisms with response to intravitreal ranibizumab among neovascular agerelated macular degenerative subjects. Hum Genomics. 2019;13(1):13. https://doi.org/10.1186/s4024 6-019-0197-3.

24. Matušková $\mathrm{V}$, et al. An association of neovascular age-related macular degeneration with polymorphisms of CFH, ARMS2, HTRA1 and C3 genes in Czech population. Acta Ophthalmol. 2020;98(6): e691-9. https://doi.org/10.1111/aos.14357.

25. Yang X, Hu J, Zhang J, Guan H. Polymorphisms in $\mathrm{CFH}, \mathrm{HTRA} 1$ and CX3CR1 confer risk to exudative age-related macular degeneration in Han Chinese. Br J Ophthalmol. 2010;94(9):1211-4. https://doi. org/10.1136/bjo.2009.165811.

26. Tong $\mathrm{Y}$, et al. LOC387715/HTRA1 gene polymorphisms and susceptibility to age related macular degeneration: a HuGE review and meta-analysis. Mol Vis. 2010;16:1958-81. http://www.molvis.org/ molvis/v16/a213.

27. Lin $\mathrm{MK}$, et al. HTRA1, an age-related macular degeneration protease, processes extracellular matrix proteins EFEMP1 and TSP1. Aging Cell. 2018; 17(4):e12710. https://doi.org/10.1111/acel.12710.

28. Nakayama M, et al. Overexpression of HtrA1 and exposure to mainstream cigarette smoke leads to choroidal neovascularization and subretinal deposits in aged mice. Investig Ophthalmol Vis Sci. 2014;55(10):6514-23. https://doi.org/10.1167/iovs. 14-14453.

29. Yi Chen C, et al. N-Terminomics identifies HtrA1 cleavage of thrombospondin-1 with generation of a proangiogenic fragment in the polarized retinal pigment epithelial cell model of age-related macular degeneration. Matrix Biol. 2018;70:84-101. https://doi.org/10.1016/j.matbio.2018.03.013.

30. Vierkotten S, Muether PS, Fauser S. Overexpression of HTRA1 leads to ultrastructural changes in the elastic layer of Bruch's membrane via cleavage of extracellular matrix components. PLOS ONE. 2011;6(8):e22959. https://doi.org/10.1371/journal. pone.0022959.

31. Tosi GM, et al. HTRA1 and TGF- $\beta 1$ concentrations in the aqueous humor of patients with neovascular age-related macular degeneration. Investig Ophthalmol Vis Sci. 2017;58(1):162-7. https://doi.org/ 10.1167/iovs. 16-20922.

32. Kubicka-Trzaska A, Karska-Basta I, Dziedzina S, Sanak M, Romanowska-Dixon B. HTRA1 rs11200638 and ARMS2 rs10490924 gene polymorphisms and response to intravitreal anti-VEGF treatment in patients with exudative age-related macular degeneration. Klin Oczna. 2019;2019(1): 34-40. https://doi.org/10.5114/ko.2019.84560.

33. Zhou YL, et al. Association between polymorphism rs11200638 in the HTRA1 gene and the response to anti-VEGF treatment of exudative AMD: a metaanalysis. BMC Ophthalmol. 2017;17(1):97. https:// doi.org/10.1186/s12886-017-0487-2. 